\title{
Article \\ Effectiveness of Multifunctional Margins in Insect Biodiversity Enhancement and RTE Species Conservation in Intensive Agricultural Landscapes
}

\author{
Fernando Santa ${ }^{1} @$, Luis Oscar Aguado ${ }^{2}$, José Vicente Falcó-Garí ${ }^{3}{ }^{\circledR}$, Ricardo Jiménez-Peydró $^{3}$, Michael Schade $^{1}$, \\ Vasileios Vasileiadis ${ }^{1}$, Luis Miranda-Barroso ${ }^{4}\left(\mathbb{D}\right.$ and Francisco Javier Peris-Felipo ${ }^{1, *} \mathbb{B}$ \\ 1 Syngenta Crop Protection, Rosentalstrasse 67, 4058 Basel, Switzerland; fernando.santa@novaims.unl.pt (F.S.); \\ michael.schade@syngenta.com (M.S.); vasileios.vasileiadis@syngenta.com (V.V.) \\ 2 Andrena Iniciativas y Estudios Medioambientales S.L. c/. Gabilondo 16bis, 47007 Valladolid, Spain; \\ oscaraguado@lepidopteros.com \\ 3 Laboratory of Entomology and Pest Control, Institute Cavanilles of Biodiversity and Evolutionary Biology, \\ c/Catedrático José Beltrán 2, 46980 Valencia, Spain; j.vicente.falco@uv.es (J.V.F.-G.); \\ ricardo.jimenez@uv.es (R.J.-P.) \\ 4 Agricultura Sostenible Syngenta España, c/. de la Ribera del Loira, 28042 Madrid, Spain; \\ luis.miranda@syngenta.com \\ * Correspondence: javier.peris@syngenta.com; Tel.: +41-766-908-032
}

check for updates

Citation: Santa, F.; Aguado, L.O.; Falcó-Garí, J.V.; Jiménez-Peydró, R.; Schade, M.; Vasileiadis, V.; Miranda-Barroso, L.; Peris-Felipo, F.J. Effectiveness of Multifunctional Margins in Insect Biodiversity Enhancement and RTE Species Conservation in Intensive Agricultural Landscapes. Agronomy 2021, 11, 2093. https://doi.org/ 10.3390/agronomy11112093

Academic Editor:

Marie-Stéphane Tixier

Received: 18 August 2021

Accepted: 14 October 2021

Published: 20 October 202

Publisher's Note: MDPI stays neutral with regard to jurisdictional claims in published maps and institutional affiliations.

Copyright: (c) 2021 by the authors. Licensee MDPI, Basel, Switzerland. This article is an open access article distributed under the terms and conditions of the Creative Commons Attribution (CC BY) license (https:// creativecommons.org/licenses/by/ $4.0 /)$

\begin{abstract}
Starting in the 1950s, agricultural production has been remarkably intensified, resulting in modern management systems where a severe increase in field size led to an elimination of edges and other ecologically valuable structural elements. The resulting habitat loss caused dramatic changes in natural communities. The aim of this work is to test whether there are statistically significant differences in insect abundance over time by using multifunctional margins that are seed mixtures of autochthonous species planted in combined strips, which are the fastest way to provide significant biodiversity benefits within farmed landscapes, enhancing the diversity and abundance of insects, birds, and small mammals, offering resources and reservoirs. This study was carried out in three intensive fruit farms in Spain over a three-year period (2013-2015). Each field was divided into two zones: the margin where a multifunctional margin was planted, and another that remained unchanged in the field. A clear trend to increase RTE species throughout the years in all farms was observed. Moreover, the margin showed a significant difference with respect to the field in the average number of insect species and individuals. The use of margins improves the appearance of RTE species in mean percentages ranging between 12.06 and $25.26 \%$ according to the sampling area. Margins also favour the increase in species (148.83-232.84\%) and individuals (207.24-586.70\%) in agricultural landscapes. These results clearly show that margins are an essential tool to fight insect decline in intensive farming areas.
\end{abstract}

Keywords: agro-ecosystems; sustainability; habitat management; cover plants; natural enemies; RTE species; stone fruits

\section{Introduction}

The substitution of heterogeneous agricultural landscapes by homogeneous ones, together with the increased adoption of intensive agricultural practices, has resulted in accelerated environmental deterioration and the associated loss of whole taxonomic groups [1-5]. Various studies show that the influence of changing agricultural practices since the second half of the 20th century negatively impacted species richness, abundance, and biomass, and led to shifts in species composition [6-14]. Reviews prove that six key factors are responsible for the biodiversity decline: (1) habitat loss, fragmentation, and degradation; (2) invasive species; (3) parasites and diseases; (4) non-sustainable use of pesticides; (5) extinction cascades; and (6) climate change [15-17]. 
Biodiversity decline has been mainly reported in wild bees, honeybees, hoverflies, butterflies, wasps, birds, and mammals $[18,19]$ through comprehensive studies carried out in Europe and North America. Given the fact that these regions boast a long history of agricultural activity, it is likely that farming impacted the most sensitive species even before studies started to investigate such effects. It is therefore not possible to claim that these studies are representative of what is happening globally [20,21], as intensive farming activities set in quite late in many tropical areas [19].

Pollinating insects have been severely affected by land-use change and are suffering the highest decline $[10,15,22-27]$. A recent review on land-use intensity showed a divergent effect on cropland pollinator biodiversity between non-tropical and tropical areas. In non-tropical areas, species and abundance did not differ significantly among minimal, light, and intense land-use, while in tropical areas species richness decreased by $44-49 \%$ in an intense land-use scenario compared to one with minimal farming activities [19].

Global crop production heavily depends on ecosystem services from pollinators. The value of such services is estimated at USD 235-577 billion per year the world over [28]. For this reason, over the past 40 years, several studies have tried to investigate the causes behind declining insect populations and proposed measures to protect and enhance biodiversity in agricultural landscapes [29-37]. Most commonly, these studies focused on implementing hedgerows, field margins, floral margins, or flower and herb strips, which provide significant biodiversity benefits within farmed landscapes. As a matter of fact, these measures are suitable to enhance the diversity and abundance of insects, birds, and small mammals, offering them habitats, nesting places, and food resources [34,35,37-51].

Studies focusing on biodiversity in rural areas are critically important to gain a deeper knowledge of how ecosystems in such areas function and to understand what type of measures are suitable to protect and conserve biodiversity and to enhance biodiversity in agricultural landscapes [52-59].

In the present work, we focus on RTE (Rare, Threatened, and Endangered) species and we test three hypotheses. First, we check whether the implementation of multifunctional margins effectively increases the probability of finding RTE species. Our second hypothesis is that the use of field margins correlates with an increase in the number of species. Finally, we test the assumption that the use of field margins also boosts the number of individuals. The second and the third hypotheses are tested irrespective of whether a species or an individual falls into the RTE category. These hypotheses were studied in three intensive fruit farms in Spain.

\section{Materials and Methods}

\subsection{Areas of Study}

The study was carried out in three highly productive Spanish stone fruit farms located in Águilas (Murcia; $37^{\circ} 37^{\prime} 04.7^{\prime \prime} \mathrm{N}, 0^{\circ} 47^{\prime} 08.1^{\prime \prime} \mathrm{W}$ ), Alcarràs (Lérida; $41^{\circ} 34^{\prime} 39.2^{\prime \prime} \mathrm{N}$, $0^{\circ} 30^{\prime} 24.4^{\prime \prime} \mathrm{E}$ ), and Fuliola (Lérida; $41^{\circ} 43^{\prime} 13.62^{\prime \prime} \mathrm{N}, 0^{\circ} 59^{\prime} 53.56^{\prime \prime} \mathrm{E}$ ) (Figure 1). Lérida farms have a slightly continental Mediterranean climate with hot summers and cold winters where the annual rainfall is approx. $340 \mathrm{~mm}$, while Águilas presents a semi-arid Mediterranean climate with hot summers and mild winters with an annual rainfall of $201 \mathrm{~mm}$ [60].

The crops covered in our study are peaches (on the Águilas farm) and nectarines (on the Alcarràs and Fuliola farms), which are planted in a standard-conventional design, with tree lines separated by $5 \mathrm{~m}$ and with trees of a same row planted approximately every $2 \mathrm{~m}$. All fields are of equal size (6 ha each).

During the study, all farms stuck to their preferred agricultural practices such as tillage, sowing, and fertilisation, and phytosanitary treatments remained unchanged. Any management measures were was confined to the crop to avoid trying not to interfere with the multifunctional margin. 


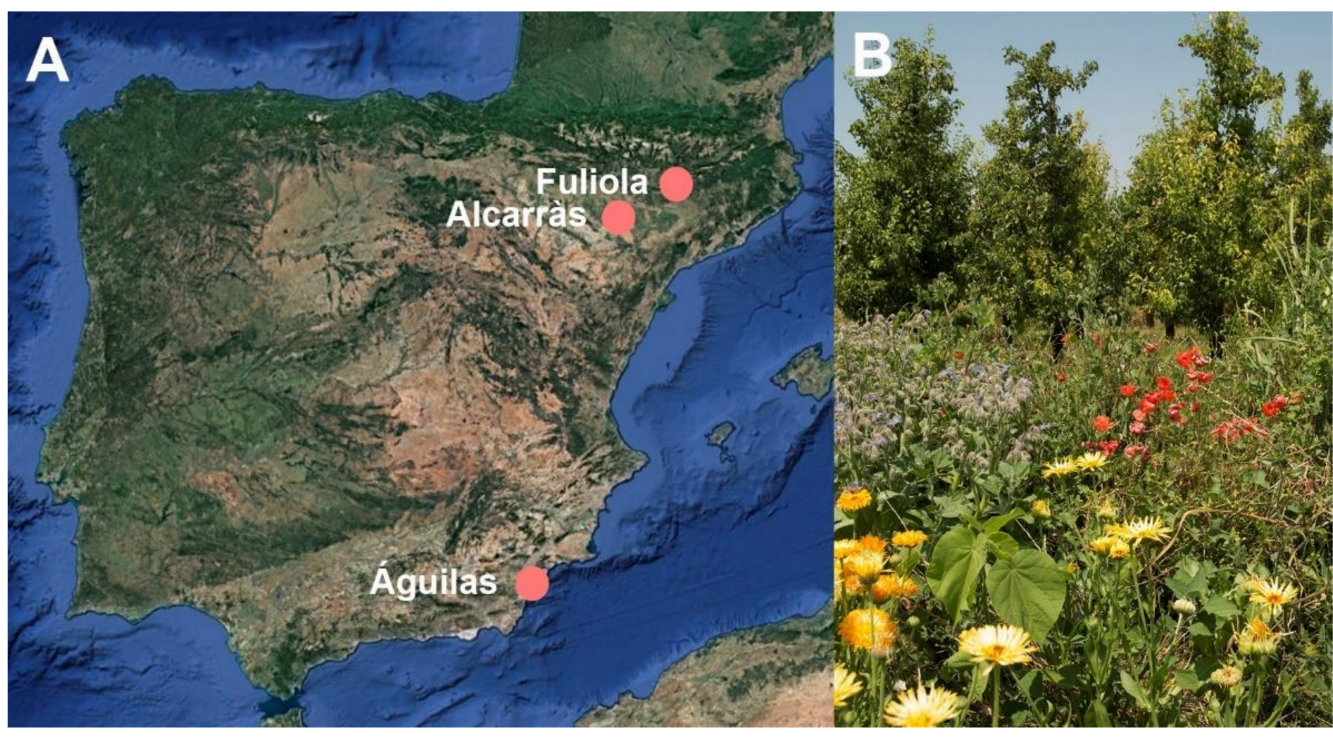

Figure 1. (A) Farm location in Spain. (B) Multifunctional margin in Fuliola (Lérida) farm.

\subsection{MFM Mixture Plant Selection}

Multifunctional margins (MFM) are seed mixtures of autochthonous species planted in combined strips, which are the fastest way to provide significant biodiversity benefits within farmed landscapes, enhancing the diversity and abundance of insects, birds, and small mammals, offering resources and reservoirs. The selection of plant species was based on several fundamental criteria, such as the strict use of native species, ensuring a smooth climatic adaptation; being non-weed for the crop; featuring easy maintenance and capacity for self-sowing, as well as staggered flowering phenologies; and finally, being attractive for pollinators and natural enemies.

MFM were established using an herbaceous mixture consisting of Borago officinalis L. (10\%), Calendula officinalis L. (22.5\%), Coriandrum sativum L. (10\%), Diplotaxis catholica (L.) DC. (5\%), Echium vulgare L. (5\%), Melilotus officinalis (L.) Pall. (12.5\%), Nigella damascena (L.) (5\%), Salvia verbenaca L. (10\%), Silene vulgaris (Moench) Garcke (10\%), and Vicia sativa L. (10\%). This mixture was sown in January 2013 in an area of $200 \mathrm{~m}$ length $\times 3 \mathrm{~m}$ width separated about $5 \mathrm{~m}$ from the field edge to favour management by an electric drill with air distribution after the soil preparation by flail mower and subsequent covering of the seed with a drag. The sowing dose used was $15 \mathrm{~kg} / \mathrm{Ha}$. The margins were mowed in autumn and then left to regrow.

\subsection{Experimental Design and Sampling}

The experiment was conducted for 3 years (2013-2015) to investigate the dynamics of effects of multifunctional margins on RTE species. On each farm a plot was selected, and this field was divided into two zones: field and margin. The field was kept clean of cover plants, weeds, or spontaneous vegetation through the application of a residual herbicide at the beginning of the season and through the mechanical removal of weeds during the season. In the field margin, a line of herbaceous mixture was sown.

The insect abundance was assessed visually and using a sweeping net. All observations were made by moving in a zigzag along fixed transects of $50 \mathrm{~m} \times 2 \mathrm{~m}$ during $15 \mathrm{~min}$ per line and four times per day to avoid the light and temperature gradient and obtain a more representative sample. Observed and captured specimens were merged to perform the corresponding analyses. Sampling took place five times a year following the stone fruit tree growth stages (shooting, blossoming, fruit setting, harvest, and senescence of leaves) coinciding with the vegetative period of the multifunctional margin plants.

Collected specimens were preserved in cyanide to keep them intact and to avoid discoloration. All specimens were identified to species level using appropriate entomological 
literature (see [61-75]). After their identification, the species were catalogued according to the IUCN Red List [76]. For the data analysis, we focused only on RTE species. Specimens are deposited in the entomological collection of the National Museum of Natural Sciences (Madrid, Spain; MNCN).

\subsection{Statistical Analysis}

First, an exploratory data analysis was initially performed to describe the behaviour of the percentage of RTE species, the abundance of species, and the abundance of individuals under the evaluated factors. Second, to test our hypotheses, we used an approach based on fitting regression models to explain the presence of RTE species, the number of species, and the number of individuals. Then, we estimated three generalised linear models (GLM), one for a binary variable and two for count data, respectively.

\subsubsection{Model for RTE Species}

For evaluating the impact of MFM and their consistency through time in decreasing the pressure over RTE species, a logistic regression model is fitted. To perform this, we define the binary random variable:

$$
Z=\left\{\begin{array}{c}
1 \text { if there is at least one identified insect specimen considered at risk } \\
0 \text { in any other case }
\end{array}\right.
$$

Based on Equation (1), we establish the logistic regression model as follows:

$$
\log \left(\frac{\pi_{i j k l_{o_{k}}}}{1-\pi_{i j k l_{o_{k}}}}\right)=\mu+\alpha_{i}+\beta_{j}+\gamma_{k}+\varepsilon_{i j k l_{o_{k}}}\left\{\begin{array}{c}
i=1,2 \\
j=1,2,3 \\
k=1,2,3 \\
l=1,2, \ldots, o_{k}
\end{array}\right.
$$

where $\pi_{i j k l_{o_{k}}}$ represents the probability of finding at least one individual of a species at RTE in the $i$ th zone, $j$ th year, and $k$ th farm. $o_{k}$ is the number of identified species in the $k$ th farm. The left part in Equation (2) is known as the logit function and it is interpreted as the logarithm of odds [77]. In Equation (2), $\alpha_{i}$ is the zone, $\beta_{j}$ is the year, and $\gamma_{k}$ is the farm.

\subsubsection{Models for Abundance of Species and Individuals}

Similarly, as the previous case, to test the effect of the implemented measures and their evolution in the abundance of species and individuals, we define two GLM for count data, respectively, as follows:

$$
g\left(n_{i j k l}\right)=\mu+\alpha_{i}+\beta_{j}+\gamma_{k}+\delta_{l}+\varepsilon_{i j k l}\left\{\begin{array}{c}
i=1,2 \\
j=1,2,3 \\
k=1,2,3 \\
l=1,2
\end{array}\right.
$$

where $n_{i j k l}$ represents the number of species in the $i$ th zone, $j$ th year, $k$ th farm, and $l$ th type of species (see Equation (1)).

$$
g\left(n_{i j k l m_{o_{k}}}\right)=\mu+\alpha_{i}+\beta_{j}+\gamma_{k}+\delta_{l}+\varepsilon_{i j k l m_{o_{k}}}\left\{\begin{array}{c}
i=1,2 \\
j=1,2,3 \\
k=1,2,3 \\
l=1,2 \\
m=1,2, \ldots, o_{k}
\end{array}\right.
$$

where $n_{i j k l m_{o_{k}}}$ represents the number of individuals in the $i$ th zone, $j$ th year, $k$ th farm, and $l$ th type of species. $o_{k}$ is the number of identified species in the $k$ th farm.

In Equations (3a) and (3b), $g$ is a monotonous function that linearises the relationship between the response variable and the systematic component of the model, such as loga- 
rithm or root square for a Poisson model. It is usually assumed that the response variable, i.e., $n_{i j k l}$ or $n_{i j k l m_{o_{k}}}$, follows a Poisson distribution when its mean and variance are equal or a negative binomial when its variance is greater than its mean (overdispersion) [78]. Here, $\alpha_{i}$ is the zone, $\beta_{j}$ is the year, $\gamma_{k}$ is the farm, and $\delta_{l}$ is the type of species.

The parameters of three models in Equations (2), (3a) and (3b) were estimated via maximum likelihood. For the models in Equations ( $3 a$ ) and ( $3 b)$, we consider and evaluate a Poisson and a negative binomial distribution for the response variable. The fitted count data models are compared to choose the best probability distribution of the response variable by using a likelihood ratio (LR) contrast [79]. We address all statistical data analysis in R statistical software [80]. Particularly, for fitting the models, we use the glm and glm.nb function from packages stats and MASS, respectively. For statistical inference over the fitted GLM, we use the deviance, AIC, and BIC functions from stats package, Anova function from car package, and lrtest from lmtest package.

\section{Results}

\subsection{Diversity of Insects}

A total of 3305 insects were captured during the three-year research programme. Of these insects, 1828 individuals were sampled from Águilas and 894 and 583 individuals from Alcarràs and Fuliola, respectively (Table 1). In Águilas, 154 species (74 from the field and 139 from the margin) were identified, of which 57 species (24 from the field and 54 from the margin) are listed in the Red List. On the other hand, 46 species were captured (31 from the field and 45 from the margin) from Alcarràs, of which 19 species are registered in the Red List (12 in the field and 19 in the margin). Finally, in Fuliola, 57 species ( 39 from the field and 54 from the margin) were identified, of which 27 species (20 from the field and 26 from the margin) had been catalogued in the Red List.

Table 1. Abundance of species and individuals by farm and zone through the years.

\begin{tabular}{ccccccccc}
\hline \multirow{5}{*}{ Location } & \multicolumn{2}{c}{ 2013 } & \multicolumn{2}{c}{ 2014 } & \multicolumn{2}{c}{ 2015 } \\
\cline { 3 - 8 } & & Field & Margin & Field & Margin & Field & Margin \\
\hline \multirow{3}{*}{ Species } & Águilas & 26 & 54 & 51 & 79 & 57 & 131 \\
& Alcarràs & 11 & 14 & 23 & 36 & 25 & 44 \\
& Fuliola & 12 & 12 & 22 & 42 & 36 & 53 \\
\hline \multirow{3}{*}{ Individuals } & Águilas & 52 & 389 & 122 & 377 & 141 & 747 \\
& Alcarràs & 35 & 32 & 91 & 233 & 104 & 399 \\
& Fuliola & 38 & 33 & 73 & 107 & 127 & 205 \\
\hline
\end{tabular}

Analysing the species by category, we observe that all species were catalogued as LC (Least Concern) except Epeolus cruciger (Panzer, 1799) (Hymenoptera: Apidae) and Halictus quadricinctus (Fabricius, 1776) (Hymenoptera: Halictidae), which belong to the NT (Near Threatened) category. Of these NT species, one individual of Epeolus was captured from Águilas in the margin zone (in 2015), while three Halictus individuals were found in Alcarràs and Fuliola also in the multifunctional margin in 2015. However, these two NT species were never captured from the field zone.

\subsection{GLM Modelling}

Figure 2 and Table A1 show the changes in the average of percentage of presence of RTE species, the total number of identified species, and the total number of insects between zones, farms, and years, respectively. All three measures of biodiversity and abundance show a trend of increasing their average through the years in all farms. However, these trends differ between farms, varying the rate of change. In all the cases, the zones in the margins of the farms have higher averages in comparison with the zones in the fields. In most of the cases, the variability of the percentage of RTE species, the number of species, and the number of individuals in the margins is bigger than in the fields, showing the 
complexity of insect population dynamics among the contrasting farming environments. Finally, there is not an observed interaction effect among the zones and the years.
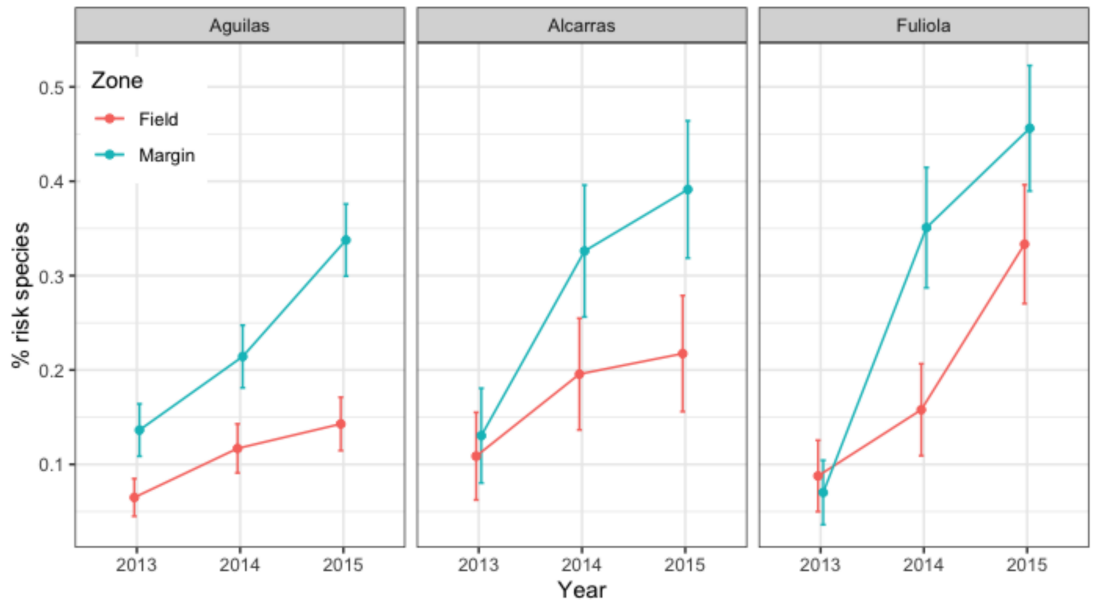

(a)
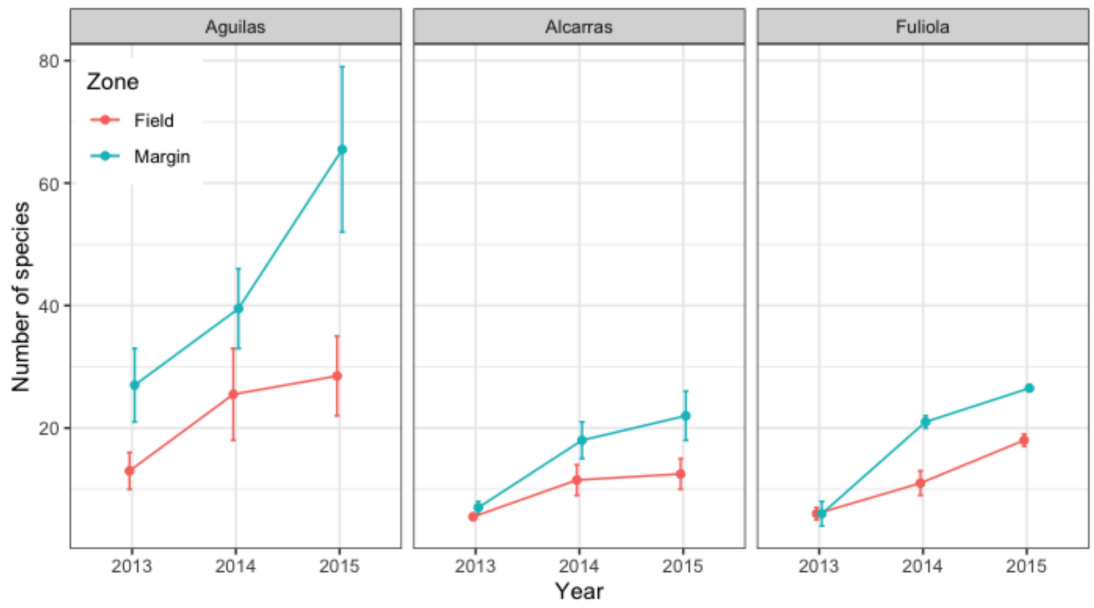

(b)
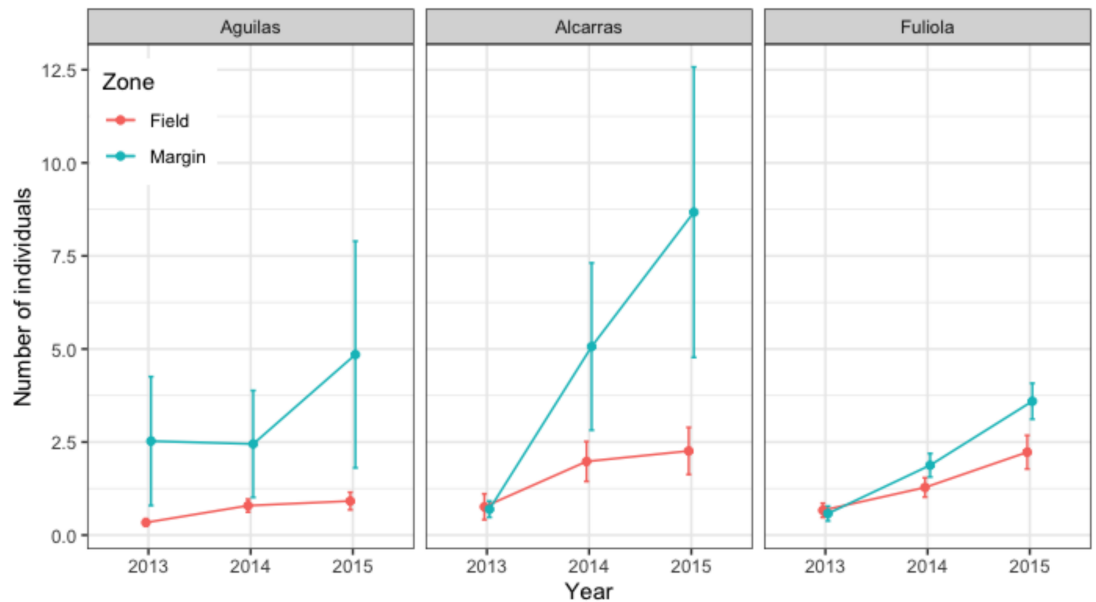

(c)

Figure 2. Plot of means and standard error bars of the percentage of RTE species, the total number of species, and the total number of individuals between zones across the farms through the years. (a) Percentage of RTE species. (b) Abundance of species. (c) Abundance of individuals. 


\subsubsection{Model for RTE Species}

We estimated a logistic regression model based on Equation (2). The reference categories were Location: Aguilas, Year: 2013, and Zone: Field. Table 2 presents the statistics for the goodness of fit and the analysis of deviance to the adjusted model. The LR test shows that the model has a better fit than the null model (model without explanatory variables). We then concluded that the model is acceptable to explain the percentage of RTE species as a function of the examined systematic component, i.e., zones, years, and farms, since the deviance statistic is also statistically significant. The analysis of deviance also shows that the related parameters are all statistically significant, which means that there are differences due to main effects, zones, and years, and the blocking effect the farm.

Table 2. Statistics of goodness of fit and the analysis of deviance table (Type II Wald chi-square tests) in the fitted logistic regression model for the percentage of RTE species.

\begin{tabular}{|c|c|c|c|c|}
\hline \multicolumn{5}{|c|}{ Statistics of Goodness of Fit } \\
\hline \multicolumn{2}{|c|}{ Likelihood ratio (LR) } & \multicolumn{3}{|c|}{$104.8^{* * *}$} \\
\hline \multicolumn{2}{|c|}{ Deviance (D) } & \multicolumn{3}{|c|}{1420.5 * } \\
\hline \multicolumn{2}{|c|}{ AIC } & \multicolumn{3}{|c|}{1432.5} \\
\hline \multicolumn{2}{|c|}{$\mathrm{BIC}$} & \multicolumn{3}{|c|}{1464.5} \\
\hline \multicolumn{5}{|c|}{ Analysis of Deviance Table } \\
\hline Source & LR Chisq & Df & $p$-value & \\
\hline Farm & 11.42 & 2 & 0.003 & ** \\
\hline Year & 61.62 & 2 & $4.170 \times 10^{-14}$ & $* * *$ \\
\hline Zone & 33.80 & 1 & $6.125 \times 10^{-9}$ & $* * *$ \\
\hline
\end{tabular}

*** $[0,0.001] ; * *[0.001,0.01] ; *[0.01,0.05] ;[0.05,0.1] ;[0.1,1]$.

Table 3 shows the estimated parameters of the logistic regression model and the odds ratio with their $95 \%$ confidence intervals. This fitted model shows that, holding farm and year at a fixed value, the odds of getting at least one individual of an RTE species in the margin (Zone: Margin =1) over the odds of getting at least one individual of an RTE species in the field (Zone: Margin $=0$ ) are $\exp (0.78)=2.18$. In terms of percent change, we can say that the odds for the margin are $118 \%$ higher than the odds for the field. Similarly, the associated coefficients with year show that, holding farm and zone at a fixed value, we will see a $135 \%$ and $277 \%$ increase in the odds of obtaining at least one individual of an RTE species in the years 2014 and 2015 with respect to the year 2013 since $\exp (0.85)=2.35$ and $\exp (1.33)=3.77$.

Table 3. Estimated regression coefficients, odds ratios, and $95 \%$ confidence intervals in the fitted logistic regression model for the percentage of RTE species.

\begin{tabular}{ccccc}
\hline Parameter & Estimate & OR & $\mathbf{2 . 5 \%}$ & $\mathbf{9 7 . 5 \%}$ \\
\hline Intercept & -2.85 & 0.06 & 0.04 & 0.08 \\
Location: Alcarras & 0.40 & 1.49 & 1.06 & 2.09 \\
Location: Fuliola & 0.49 & 1.63 & 1.19 & 2.22 \\
Zone: Margin & 0.78 & 2.18 & 1.67 & 2.85 \\
Year: 2014 & 0.85 & 2.35 & 1.64 & 3.41 \\
Year: 2015 & 1.33 & 3.77 & 2.67 & 5.4 \\
\hline
\end{tabular}

\subsubsection{Models for Abundance of Species and Individuals}

We fitted four count GLM based on Equations ( $3 a$ ) and ( $3 b$ ) by considering a Poisson and a negative binomial response. Table A2 presents the statistics for the goodness of fit to the estimated models. For the case of the number of identified species, based on the LR test and deviance statistic, both models have approximately the same fit. However, AIC and BIC statistics are slightly lower for the model that assumes the Poisson distribution for the response variable, which means that the Poisson distribution seems to be an adequate 
probabilistic schema for the number of species. For the case of the number of identified individuals, the LR test shows a better fit in the model that uses a negative binomial distribution for the response variable, which means that the variance of the count of individuals increases more rapidly than their mean and the negative binomial distribution is more accurate as a probabilistic schema for the number of individuals. Moreover, the other statistics of goodness of fit such as AIC and BIC are considerably lower for the model that assumes the negative binomial distribution for the response variable.

Based on the previous results, we selected the Poisson model for the number of species and the negative binomial for the number of individuals as preferred models. Tables 4 and 5 show the analysis of deviance and the estimated parameters with their associated confidence interval for the preferred GLM, respectively. In both cases, the statistical inference in the models shows that the effects, zone, year, and farm, are statistically significant. The related parameters are also significant and reveal an increase in the number of species and individuals with time and in the margins. However, there is a difference between the model for the abundance where the parameter associated with the RTE species is significant in the case of the number of species but not in the number of individuals.

Table 4. Analysis of deviance table (Type II Wald chi-square tests) in the fitted count regression model for the number of identified species and individuals.

\begin{tabular}{cccccccccc}
\hline \multicolumn{4}{c}{ Model for the Number of Identified Species } & \multicolumn{4}{c}{ Model for the Number of Identified Individuals } \\
\hline Source & LR Chisq & Df & $\boldsymbol{p}$-Value & & Source & LR Chisq & Df & $p$-Value \\
\hline Farm & 141.0 & 2 & $<2.2 \times 10^{-16}$ & $* * *$ & Farm & 15.1 & 2 & 0.0005293 \\
Zone & 56.8 & 1 & $4.85 \times 10^{-14}$ & $* * *$ & Zone & 128.7 & 1 & $<2.2 \times 10^{-16}$ & $* * *$ \\
Year & 103.6 & 2 & $<2.2 \times 10^{-16}$ & $* * *$ & Year & 66.3 & 2 & $4.11 \times 10^{-15}$ & $* * *$ \\
Type of species & 21.2 & 1 & $4.09 \times 10^{-6}$ & $* * *$ & Type of species & 1.6 & 1 & 0.2106602 \\
\hline
\end{tabular}

$* * *[0,0.001]$.

Table 5. Estimated regression coefficients in the fitted count regression model for the number of identified species and individuals.

\begin{tabular}{cccccccc}
\hline \multicolumn{3}{c}{ Model for the Number of Identified Species } & \multicolumn{3}{c}{ Model for the Number of Identified Individuals } \\
\hline Parameter & Estimate & $\mathbf{2 . 5 \%}$ & $\mathbf{9 7 . 5 \%}$ & Parameter & Estimate & $\mathbf{2 . 5 \%}$ & $\mathbf{9 7 . 5 \%}$ \\
\hline Intercept & 2.70 & 2.48 & 2.92 & Intercept & -0.76 & -1.00 & -0.52 \\
Location: Alcarras & -0.96 & -1.15 & -0.77 & Location: Alcarras & 0.49 & 0.23 & 0.76 \\
Location: Fuliola & -0.81 & -0.99 & -0.64 & Location: Fuliola & 0.01 & -0.24 & 0.27 \\
Zone: Margin & 0.57 & 0.42 & 0.72 & Zone: Margin & 1.20 & 0.99 & 1.40 \\
Year: 2014 & 0.67 & 0.46 & 0.89 & Year: 2014 & 0.56 & 0.31 \\
Year: 2015 & 0.99 & 0.79 & 1.19 & Year: 2015 & 1.03 & 0.78 \\
Type of species: RTE & -0.34 & -0.49 & -0.20 & Type of species: RTE & 0.16 & -0.09 & 0.41 \\
\hline
\end{tabular}

\section{Discussion}

Even if biotopes in the Mediterranean area are often not suitable for human intervention, urbanisation, infrastructures, and agricultural activities have led to isolation and fragmentation and the emergence of isolated biodiverse patches within the landscape [81]. The creation of multifunctional margins (MFM), banker plants, headlands, or hedges sown with a species-rich seed mixture has resulted in the fast recovery of insects, with biodiverse and abundant populations [37,51,82-89]. According to our first working hypothesis, the integration of multifunctional margins increases the probability of finding RTE species. There are clear differences between field margin and field. While there is a clear trend in both zones for the likelihood of identifying more RTE species, this trend is much stronger in field margins than in the fields. As a matter of fact, the probability of finding RTE species in Águilas increased from $13.63 \%$ to $33.76 \%$ in the margin and from $6.49 \%$ to $14.28 \%$ in the field. In Alcarràs, the probability significantly rose from $13.04 \%$ to $39.13 \%$ in the margin and from $10.89 \%$ to $21.73 \%$ in the field. In Fuliola, the values went up from $7.01 \%$ to $45.61 \%$ 
in the margin and from $8.77 \%$ to $33.33 \%$ in the field. Looking at the mean value for all three farms taken together, the probability increased from $12.06 \%$ to $37.35 \%$ in the margin and from $7.78 \%$ to $19.84 \%$ in the field. We must be aware that an increased probability of finding RTE species can also be triggered by the occurrence of only one or two species in the area examined. Therefore, it is necessary to closely look at the trend in the number of species and individuals in order to obtain a more approximate interpretation of the data. Indeed, the use of plant mixtures can play a very important role in the speed of biodiversity enhancement. Similar observations were also made by authors such as Hannon and Sisk [90], who considered that flowering shrubs are important in attracting bees (that were otherwise uncommon in the landscape) and further pollinators that may play a valuable role in pollinating agricultural crop plants.

According to our second working hypothesis, selecting the right plants can improve the number of insect species. The results from the present study show that there is a clear increase in the number of species both in the field and in the margin. Within three years, the number of species identified in Águilas grew from 26 to 57 (by 119.23\%) and from 54 to 131 (by 142.59\%) in the margin zone. A similar development could be registered for Alcarràs and Fuliola. There, the increase in the field was $127.27 \%$ and $200.00 \%$, respectively, and the increase in the field margin was $214.28 \%$ and $341.66 \%$. All three sites taken together, the number of species identified in the field rose by $148.83 \%$ and in the field margin by $232.84 \%$. This confirms the findings of several other studies that MFM play an important role in the presence of abundant insect species $[50,76-80,83,84]$. However, only two such studies examined insect species over three consecutive growing seasons. Miranda-Barroso et al. [91] registered an increase of $102.47 \%$ in an alfalfa field, while Peris-Felipo et al. [92] found that the number of species identified on five intensively managed wine farms rose by $12.10 \%$ after three years of using cover crops. On the other hand, the analysis of RTE species of the three studied stone fruit farms showed that $42.77 \%$ of species (77 of $180 \mathrm{spp}$.) are extinction RTE according to the IUCN Red List (2021), while Miranda et al. [91] noted a value of $33.74 \%$ (55 of $163 \mathrm{spp}$.). These results underline the importance of MFM and plant mixtures as strategies to support the conservation of species in intensively farmed areas. With regard to this, various authors have suggested that future conservation strategies need to assess whether it is better to minimise further habitat losses or whether it makes more sense to enhance agricultural landscapes with measures such as smartly composed multifunctional margins [17,35,37,44-51,91-94].

Finally, following our third hypothesis, we observed that the number of individuals increased significantly in the field and margin over time. Numerous researchers have studied the effect of the impact of plant mixtures on the abundance of insects [49,50,82-88,91,92]. Our results demonstrate that, in Águilas, the number of individuals in the field grew from 52 to 151 (190.38\%), while the number went up from 389 to 747 in the field margin (plus 92.03\%). In Alcarràs and Fuliola, the number of individuals collected in the field rose by $197.14 \%$ and $234.21 \%$, respectively. In the field margins of these farms, the increase registered was $521.21 \%$ and $1146.87 \%$, respectively. With all three farms taken together, the number of individuals identified increased by $207.24 \%$ in the field and by $586.70 \%$ in the field margin. These values are bigger than those obtained by Miranda-Barroso et al. [91] in one alfalfa field and Peris-Felipo et al. [92] in five intensively managed wine farms, where they observed an increase of $97.64 \%$ and $40.01 \%$, respectively.

The results obtained show that the implementation of MFM and the appropriate selection of plant species based on basic criteria (see Materials and Methods) substantially increase the number of pollinating insect species and individuals over the years. This phenomenon emerges even more clearly in areas where the abundance of individuals was low at the beginning of the study. An increase in the number of pollinating insect species and individuals is of particular relevance in crops such as stone fruits, where they improve fruit curdling. Apart from these agronomic benefits, there are also ecological ones. Indeed, MFM play an important role as an insect reservoir and help to mitigate the impact from intensive agriculture on insect populations. 
We could not obtain significant results when analysing the number of individuals and distinguishing whether these were RTE or not. There is a very high variability in the number of individuals registered. This is less so the case when there is at least one RTE as in hypothesis 1 and Equation (1).

\section{Conclusions}

Implementing multifunctional margins in intensive farmed landscapes clearly promotes biodiversity conservation. Field margins sown with plant mixtures indeed play an important role for the conservation of RTE species and for enhancing the abundance of species and individuals in the short term and keeping it up in the longer term. In addition, we conclude that the implementation of these measures should be considered an essential and permanent strategy for biological conservation.

Author Contributions: Conceptualisation, F.J.P.-F. and F.S.; methodology, L.M.-B. and L.O.A.; software, F.S.; validation, J.V.F.-G., R.J.-P. and M.S.; formal analysis, F.S.; investigation, F.J.P.-F. and L.O.A.; resources, V.V.; data curation, L.O.A., F.J.P.-F. and F.S.; writing-original draft preparation, F.J.P.-F., M.S. and F.S.; writing-review and editing, F.J.P.-F. and F.S.; visualisation, F.J.P.-F.; supervision, L.M.-B.; project administration, V.V.; funding acquisition, V.V. All authors have read and agreed to the published version of the manuscript.

Funding: This research was funded by the project Operation Pollinator (Syngenta).

Data Availability Statement: The data presented in this study are available from the corresponding author upon reasonable request.

Acknowledgments: We are very thankful to the staff of G's (Águilas, Murcia), Fruits de Ponent (Alcarràs, Lérida), and Nufri (La Fuliola, Lérida) for their kindness and support during our research. Moreover, we want to thank Francisco "Paco" García Verde for his involvement and work in the launch and development of this study. Finally, we are very thankful to Rudolf Gugger for providing a new view of the MS.

Conflicts of Interest: The authors declare no conflict of interest.

\section{Appendix A}

Table A1. Descriptive statistics measures of the percentage of RTE species, the total number of species, and the total number of individuals between zones across the farms through the years.

\begin{tabular}{|c|c|c|c|c|c|c|c|c|}
\hline \multirow{2}{*}{ Farm } & \multirow{2}{*}{ Year } & \multirow{2}{*}{ Zone } & \multicolumn{2}{|c|}{ \% RTE Species } & \multicolumn{2}{|c|}{ Number of Species } & \multicolumn{2}{|c|}{ Number of Individuals } \\
\hline & & & Mean & Std. Deviation & Mean & Std. Deviation & Mean & Std. Deviation \\
\hline \multirow{6}{*}{ Aguilas } & \multirow{2}{*}{2013} & Field & 0.06 & 0.25 & 13 & 4.2 & 0.3 & 1.2 \\
\hline & & Margin & 0.14 & 0.34 & 27 & 8.5 & 2.5 & 21.5 \\
\hline & \multirow{2}{*}{2014} & Field & 0.12 & 0.32 & 26 & 10.6 & 0.8 & 2.2 \\
\hline & & Margin & 0.21 & 0.41 & 40 & 9.2 & 2.4 & 17.8 \\
\hline & \multirow{2}{*}{2015} & Field & 0.14 & 0.35 & 29 & 9.2 & 0.9 & 2.9 \\
\hline & & Margin & 0.34 & 0.47 & 66 & 19.1 & 4.9 & 37.8 \\
\hline \multirow{6}{*}{ Alcarras } & \multirow{2}{*}{2013} & Field & 0.11 & 0.31 & 6 & 0.7 & 0.8 & 2.4 \\
\hline & & Margin & 0.13 & 0.34 & 7 & 1.4 & 0.7 & 1.5 \\
\hline & \multirow{2}{*}{2014} & Field & 0.20 & 0.40 & 12 & 3.5 & 2.0 & 3.6 \\
\hline & & Margin & 0.33 & 0.47 & 18 & 4.2 & 5.1 & 15.2 \\
\hline & \multirow[b]{2}{*}{2015} & Field & 0.22 & 0.42 & 13 & 3.5 & 2.3 & 4.3 \\
\hline & & Margin & 0.39 & 0.49 & 22 & 5.7 & 8.7 & 26.5 \\
\hline \multirow{6}{*}{ Fuliola } & \multirow{2}{*}{2013} & Field & 0.09 & 0.29 & 6 & 1.4 & 0.7 & 1.4 \\
\hline & & Margin & 0.07 & 0.26 & 6 & 2.8 & 0.6 & 1.5 \\
\hline & \multirow{2}{*}{2014} & Field & 0.16 & 0.37 & 11 & 2.8 & 1.3 & 2.0 \\
\hline & & Margin & 0.35 & 0.48 & 21 & 1.4 & 1.9 & 2.4 \\
\hline & \multirow{2}{*}{2015} & Field & 0.33 & 0.48 & 18 & 1.4 & 2.2 & 3.4 \\
\hline & & Margin & 0.46 & 0.50 & 27 & 0.7 & 3.6 & 3.6 \\
\hline
\end{tabular}


Table A2. Statistics of goodness of fit for the fitted count regression models.

\begin{tabular}{|c|c|c|c|c|}
\hline \multicolumn{5}{|c|}{ Model for the Number of Identified Species } \\
\hline Test & \multicolumn{2}{|c|}{ Poisson } & \multicolumn{2}{|c|}{ Negative binomial } \\
\hline Likelihood ratio (LR) & 322.6 & $* * *$ & 94.6 & $* * *$ \\
\hline Deviance (D) & 18.1 & & 18.1 & \\
\hline AIC & 198.2 & & 200.2 & \\
\hline $\mathrm{BIC}$ & 209.3 & & 212.9 & \\
\hline \multicolumn{5}{|c|}{ Model for the Number of Identified Individuals } \\
\hline Test & \multicolumn{2}{|c|}{ Poisson } & \multicolumn{2}{|c|}{ Negative binomial } \\
\hline Likelihood ratio (LR) & 1824.2 & $* * *$ & 203.8 & $* * *$ \\
\hline Deviance (D) & $13,247.7$ & & 1316.6 & $* * *$ \\
\hline AIC & $15,205.9$ & & 5015.2 & \\
\hline $\mathrm{BIC}$ & $15,243.3$ & & 5057.9 & \\
\hline
\end{tabular}

\section{References}

1. Gaston, K.J. The magnitude of global insect species richness. Conserv. Biol. 1991, 5, 283-296. [CrossRef]

2. Mayr, E. A local flora and the biological species concept. Am. J. Botany. 1992, 79, 222-238. [CrossRef]

3. Hawksworth, D.L.; Ritchie, J.M. Biodiversity and Biosystematic Priorities: Microorganisms and Invertebrates; CAB International: Wallingford, England, 1993.

4. Wilson, P.J. Botanical diversity in arable field margins. In Field margins: Integrating Agriculture and Conservation; Boatman, N.D., Ed.; BCPC Monograph No. 58; British Crop Protection Council: Farnham, UK, 1994; pp. 53-58.

5. Otto, S.; Vasileiadis, V.P.; Masin, R.; Zanin, G. Evaluating weed diversity with indices of varying complexity in north-eastern Italy. Weed Res. 2012, 52, 373-382. [CrossRef]

6. Conrad, K.F.; Woiwod, I.P.; Parsons, M.; Fox, R.; Warren, M.S. Long-term population trends in widespread British moths. J. Insect Conserv. 2004, 8, 119-136. [CrossRef]

7. Wenzel, M.; Schmitt, T.; Weitzel, M.; Seitz, A. The severe decline of butterflies on western German calcareous grasslands during the last 30 years: A conservation problem. Biol. Conserv. 2006, 128, 542-552. [CrossRef]

8. Fox, R. The decline of moths in Great Britain: A review of possible causes. Insect Conserv. Divers. 2013, 6, 5-19. [CrossRef]

9. Hallmann, C.A.; Foppen, R.P.; van Turnhout, C.A.; de Kroon, H.; Jongejans, E. Declines in insectivorous birds are associated with high neonicotinoid concentrations. Nature 2014, 511, 641-643. [CrossRef]

10. Hallmann, C.A.; Sorg, M.; Jongejans, E.; Siepel, H.; Hofland, N.; Schwan, H.; Stenmans, W.; Müller, A.; Sumser, H.; Hörren, T.; et al. More than 75 percent decline over 27 years in total flying insect biomass in protected areas. PLoS ONE 2017, 12, e0185809. [CrossRef]

11. Habel, J.C.; Segerer, A.; Ulrich, W.; Torchyk, O.; Weisser, W.W.; Schmitt, T. Butterfly community shifts over two centuries. Conserv. Biol. 2016, 30, 754-762. [CrossRef]

12. Samways, M.J.; Barton, P.S.; Birkhofer, K.; Chichorro, F.; Deacon, C.; Fartmann, T.; Fukushima, C.S.; Gaigner, R.; Habel., J.C.; Hallmann, C.; et al. Solutions for humanity on how to conserve insects. Biol. Conserv. 2020, 242, 108427. [CrossRef]

13. Fanfarillo, E.; Kasperski, A.; Giuliani, A.; Abbate, G. Shifts of arable plant communities after agricultural intensification: A floristic and ecological diachronic analysis in maize fields of Latium (central Italy). Bot. Lett. 2019, 166, 356-365. [CrossRef]

14. Richner, N.; Holderegger, R.; Linder, H.P.; Walter, T. Reviewing change in the arable flora of Europe: A meta-analysis. Weed Res. 2015, 55, 1-13. [CrossRef]

15. McKechnie, I.M.; Thomsen, C.J.M.; Sargent, R.D. Forested field edges support a greater diversity of wild pollinators in lowbush blueberry (Vaccinium angustifolium). Agr. Ecosyst. Environ. 2017, 237, 154-161. [CrossRef]

16. Williams, P.H.; Osborne, J.L. Bumblebee vulnerability and conservation world-wide. Apidologie 2009, 40, 367-387. [CrossRef]

17. Brown, M.J.F.; Paxton, R.J. The conservation of bees: A global perspective. Apidologie 2009, 40, 410-416. [CrossRef]

18. Ollerton, J. Pollinator diversity: Distribution, ecological function, and conservation. Annu. Rev. Ecol. Evol. Syst. 2017, 48, 353-376. [CrossRef]

19. Millard, J.; Outhwaite, C.L.; Kinnersley, R.; Freeman, R.; Gregory, R.D.; Adedoja, O.; Gavini, S.; Kioko, E.; Kuhlmann, M.; Ollerton, J.; et al. Global effects of land-use intensity on local pollinator biodiversity. Nat. Commun. 2021, 12, 2902. [CrossRef]

20. Saunders, M.E.; Janes, J.K.; O'hanlon, J.C. Moving on from the insect apocalypse narrative: Engaging with evidence-based insect conservation. BioScience 2020, 70, 80-89. [CrossRef]

21. De Palma, A. Predicting bee community responses to land-use changes: Effects of geographic and taxonomic biases. Sci. Rep. 2016, 6, 31153. [CrossRef]

22. Richards, A.J. Does low biodiversity resulting from modern agricultural practice affect crop pollination and yield? Ann. Bot. 2001, 88, 165-172. [CrossRef] 
23. Biesmeijer, J.C.; Roberts, S.P.M.; Reemer, M.; Ohlemuller, R.; Edwards, M.; Peeters, T.; Schaers, A.P.; Potts, S.G.; Kleukers, R.; Thomas, C.D. Parallel Declines in Pollinators and Insect-Pollinated Plants in Britain and the Netherlands. Science 2006, 313, 351-354. [CrossRef]

24. Westphal, C.; Bommarco, R.; Carré, G.; Lamborn, E.; Morison, N.; Petanidou, T.; Potts, S.G.; Roberts, S.P.M.; Szentgyörgyi, H.; Tscheulin, T.; et al. Measuring bee diversity in di erent European habitats and biogeographical regions. Ecol. Monogr. 2008, 78, 653-671. [CrossRef]

25. Ricketts, T.H.; Regetz, J.; Steffan-Dewenter, I.; Cunningham, S.A.; Kremen, C.; Bogdanski, A.; Gemmill-Herren, B.; Greenleaf, S.S.; Klein, A.M.; Mayfield, M.M.; et al. Landscape effects on crop pollination services: Are there general patterns? Ecol. Lett. 2008, 11, 499-515. [CrossRef]

26. Potts, S.G.; Biesmeijer, J.C.; Kremen, C.; Neumann, P.; Schweiger, O.; Kunin, W.E. Global pollinator declines: Trends, impacts and drivers. Trends Ecol. Evol. 2010, 25, 345-353. [CrossRef]

27. Montero-Castaño, A.; Vilà, M. Impact of landscape alteration and invasions on pollinators: A meta-analysis. J. Ecol. 2012, 100, 884-893. [CrossRef]

28. IPBES (Intergovernmental Science-Policy Platform on Biodiversity and Ecosystem Services). The Assessment Report on Pollinators; Pollination and Food Production: Bonn, Germany, 2017.

29. Schumacher, W. Gefährdete Ackerwildkräuter können auf ungespritzten Feldrändern erhalten werden. Mitt. LÖLF 1984, 9, 14-20.

30. Jörg, E. Field Margin-Strip Programmes; Landeranstalt fur Pflanzenbau und Pflanzenschutz: Mainz, Germany, 1994.

31. De Snoo, G.R. Unsprayed field margins: Effects on environment, biodiversity and agricultural practice. Landsc. Urban Plan. 1999, 46, 151-160. [CrossRef]

32. Marshall, E.J.P.; Moonen, A.C. Field margins in northern Europe: Their functions and interactions with agriculture. Agr. Ecosyst. Environ. 2002, 89, 5-21. [CrossRef]

33. Jacot, K.; Eggenschwiler, L.; Junge, X.; Luka, H.; Bosshard, A. Improved field margins for a higher biodiversity in agricultural landscapes. Asp. Appl. Biol. 2007, 87, 277-283.

34. Smith, J.; Potts, S.G.; Woodcock, B.A.; Eggleton, P. Can arable field margins be managed to enhance their biodiversity, conservation and functional value for soil macrofauna? J. Appl. Ecol. 2008, 45, 269-278. [CrossRef]

35. Haddaway, N.R.; Brown, C.; Eggers, S.; Josefsson, J.; Kronvang, B.; Randall, N.; Uusi-Kämppä, J. The multifunctional roles of vegetated strips around and within agricultural fields. A systematic map protocol. Environ. Evid. 2016, 5, 18. [CrossRef]

36. Nowakowski, M.; Pywell, R. Habitat Creation and Management for Pollinators; Centre for Ecology \& Hydrology: Wallingford, UK, 2016.

37. Karamaouna, F.; Jacques, J.A.; Kati, V. Practices to conserve pollinators and natural enemies. Insects 2021, 12, 31. [CrossRef] [PubMed]

38. Marshall, E.J.P.; Nowakowski, M. Successional Changes in the Flora of a Sown Field Margin Strip Managed by Cutting and Herbicide Application; Brighton Crop Protection Conference-Weeds; British Crop Protection Council: Farnham, Surrey, 1995; pp. 973-978.

39. Holland, J.; Fahrig, L. Effect of woody borders on insect density and diversity in crop fields: A landscape-scale analysis. Agr. Ecosyst. Environ. 2000, 78, 115-122. [CrossRef]

40. Meek, B.; Loxton, D.; Sparks, T.; Pywell, R.; Pickett, H.; Nowakowski, M. The effect of arable field margin composition on invertebrate biodiversity. Biol. Conserv. 2002, 106, 259-271. [CrossRef]

41. Roy, D.B.; Bohan, D.A.; Haughton, A.J.; Hill, M.O.; Osborne, J.L.; Clark, S.J.; Perry, J.N.; Rothery, P.; Scott, R.J.; Brooks, D.R.; et al. Invertebrates and vegetation of field margins adjacent to crops subject to contrasting herbicide regimes in the Farm Scale Evaluations of genetically modified herbicide-tolerant crops. Philos. Trans. Royal. Soc. B. 2003, 358, 1879-1898.

42. New, T.R. Invertebrate Conservation in Agricultural Ecosystems; Cambridge University Press: Cambridge, UK, 2005.

43. Morandin, L.A.; Kremen, C. Hedgerow restoration promotes pollinator populations and exports native bees to adjacent fields. Ecol. Appl. 2013, 23, 829-839. [CrossRef]

44. Tschumi, M.; Albrecht, M.; Entling, M.H.; Jacot, K. High effectiveness of tailored flower strips in reducing pests and crop plant damage. Proc. R. Soc. B 2015, 282, 20151369. [CrossRef]

45. Holland, J.M.; Bianchi, F.J.J.A.; Entling, M.H.; Moonen, A.C.; Smith, B.M.; Jeanneret, P. Structure, function and management of semi-natural habitats for conservation biological control: A review of European studies. Pest Manag. Sci. 2016, 72, $1638-1651$. [CrossRef]

46. Castle, D.; Grass, I.; Westphal, C. Fruit quantity of strawberries benefit from enhanced pollinator abundance at hedgerows in agricultural landscapes. Agr. Ecosyst. Environ. 2019, 275, 14-22. [CrossRef]

47. Kremen, C.; Albrech, M.; Ponisio, L.C. Restoring pollinator communities and pollination services in hedgerows in intensively managed agricultural landscapes. In The Ecology of Hedgerows and Field Margins; Dover, J.W., Ed.; Routledge: London, UK, 2019.

48. Holden, J.; Grayson, R.P.; Berdeni, D.; Bird, S.; Chapman, P.J.; Edmondson, J.L.; Firbank, L.G.; Helgason, T.; Hodosn, M.E.; Hunt, S.F.P.; et al. The role of hedgerows in soil functioning within agricultural landscapes. Agr. Ecosyst. Environ. 2019, $273,1-12$. [CrossRef]

49. Sánchez, J.A.; Carrasco, A.; La Spina, M.; Pérez-Marcos, M.; Ortíz-Sanchez, F.J. How bees respond differently to field margins of shrubby and herbaceous plants in intensive agricultural crops of the Mediterranean area. Insects 2020, 11, 26. [CrossRef] 
50. Albrecht, M.; Kleijin, D.; Williams, N.M.; Tschumi, M.; Blaauw, B.R.; Bommarco, R.; Campbell, A.J.; Dainese, M.; Drummond, F.A.; Entling, M.H.; et al. Global synthesis of the effectiveness of flowers strips and hedgerows on pest control, pollination services and crop yield: A quantitative synthesis. Ecol. Lett. 2020, 23, 1488-1498. [CrossRef]

51. Iwasaki, J.M.; Hogendoorn, K. How protection of honey bees can help and hinder bee conservation. Curr. Opin. Insect Sci. 2021, 46, 112-118. [CrossRef]

52. Pyle, R.; Bentzien, M.; Opler, P. Insect conservation. Annu. Rev. Entomol. 1981, 26, 233-258. [CrossRef]

53. Pearson, D.L.; Cassola, F. World-wide species richness patterns of tiger-beetles (Coleoptera: Cicindelidae): Indicator taxon for biodiversity and conservation studies. Conserv. Biol. 1992, 6, 376-391. [CrossRef]

54. Kremen, C.; Colwell, R.K.; Erwin, T.L.; Murphy, D.D.; Noss, R.F.; Saujayan, M.A. Terrestrial arthropod assemblages: Their use as indicators in conservation planning. Conserv. Biol. 1993, 7, 796-808. [CrossRef]

55. Kremen, C.; Williams, N.M.; Thorp, R.W. Crop pollination from native bees at risk from agricultural intensification. Proc. Natl. Acad. Sci. USA 2002, 99, 16812-16816. [CrossRef]

56. Klein, A.; Vaissière, B.E.; Cane, J.H.; Stean-Dewenter, I.; Cunningham, S.A.; Kremen, C.; Tscharntke, T. Importance of pollinators in changing landscapes for world crops. Proc. Royal Soc. B 2007, 274, 303-313. [CrossRef]

57. Memmott, J.; Craze, P.G.; Waser, N.M.; Price, M.V. Global warming and the disruption of plant-pollinator interactions. Ecol. Lett. 2007, 10, 710-717. [CrossRef]

58. Goulson, D.; Lye, G.C.; Darvill, B. Decline and Conservation of Bumble Bees. Annu. Rev. Entomol. 2008, 53, 191-208. [CrossRef]

59. Morrison, J.; Izquierdo, J.; Plaza, E.H.; González-Andújar, J.L.; Hernández, E.; González-Andújar, J.L. The role of field margins in supporting wild bees in Mediterranean cereal agroecosystems: Which biotic and abiotic factors are important? Agr. Ecosyst. Environ. 2017, 247, 216-224. [CrossRef]

60. AEMET. Agencia Estatal de Meteorología. Available online: http:/ / www.aemet.es/es/portada (accessed on 26 September 2021).

61. Aguado, L.O.; Viñuelas, E.; Ferreres, A. Guía de Polinizadores de la Península Ibérica y de los Archipiélagos Balear y Canario; Ediciones Mundiprensa \& Syngenta: Madrid, Spain, 2016.

62. Amiet, F.; Herrmann, M.; Müller, A.; Neumeyer, R. Fauna Helvetica APIDAE 3: Halictus, Lasioglossum; Centre suisse de cartographie de la faune (CSCF Info Fauna) Schweizerische Entomological Gesellschaft (SEG/SES): Bern, Switzerland, 2001.

63. Amiet, F.; Hermann, M.; Müller, A.; Neumeyer, R. Fauna Helvetica APIDAE 5: Ammobates, Ammobatoides, Anthophora, Biastes, Ceratina, Dasypoda, Epeoloides, Epeolus, Eucera, Macropis, Melecta, Melitta, Nomada, Pasites, Tetralonia, Thyreus, Xylocopa; Centre suisse de cartographie de la faune (CSCF Info Fauna) Schweizerische Entomological Gesellschaft (SEG/SES): Bern, Switzerland, 2007.

64. Amiet, F.; Hermann, M.; Müller, A.; Neumeyer, R. Fauna Helvetica APIDAE 6: Andrena, Meliturga, Panurginus, Panurgus; Centre suisse de cartographie de la faune (CSCF Info Fauna) Schweizerische Entomological Gesellschaft (SEG/SES): Bern, Switzerland, 2010.

65. Cobos, A. Fauna Ibérica de Coleópteros Buprestidae; Consejo Superior de Investigaciones Científicas: Madrid, Spain, 1986.

66. Eizaguirre, S. Coleóptera, Cerambycidae. In Fauna Ibérica; Ramos, M.A., Ed.; Museo Nacional de Ciencias Naturales: Madrid, Spain; CSIC: Madrid, Spain, 2004; Volume 40.

67. Fernández-Rubio, F. Guía de las Mariposas Diurnas de la Península Ibérica, Baleares, Canarias, Azores y Madeira-1. Libytheidae, Nymphalidae, Riodinidae y Lycaenidae; Ediciones Pirámide, S.A.: Madrid, Spain, 1991.

68. Fernández-Rubio, F. Guía de las mariposas diurnas de la Península Ibérica, Baleares, Canarias, Azores y Madeira. 2. Papilionidae, Pieridae, Danaidae, Satyridae y Hesperiidae; Ediciones Pirámide, S.A.: Madrid, Spain, 1991.

69. Fernández-Rubio, F. Clave para la determinación de las especies españolas del género Zygaena Fabricius, 1775 (Insecta: Lepidoptera). Graellsia 2006, 62, 3-12. [CrossRef]

70. Martín-Piera, F.; López-Colón, J.I. Coleóptera Scarabaeoidea I. In Fauna Ibérica; Ramos, M.A., Ed.; Museo Nacional de Ciencias Naturales: Madrid, Spain; CSIC: Madrid, Spain, 2000; Volume 14.

71. Oosterbroek, P. The European Families of the Diptera. Identification, Diagnosis, Biology; KNNV Publishing: Utrecht, The Netherlands, 2006.

72. Scheuchl, E. Illustrierte Bestimmungstabellen der Wildbienen. Band I: Anthophoridae; Preisinger KG: Landhut, Germany, 2000.

73. Scheuchl, E. Taschenlexikon der Wildbienen Deutschlands und Österreichs. Band I: Megachilidae-Melittidae; Lito Tryk A/S: Berlin, Germany, 2006.

74. Séméria, Y.; Berland, L. Atlas des Néuroptères de France et d'Europe. Mégaloptères, Raphidioptères, Néuroptères Planipennes, Mécoptères; Société Nouvelle des Éditions Boubée: Paris, France, 1988.

75. Vives, E. Coleóptera, Cerambycidae. In Fauna Ibérica; Ramos, M.A., Ed.; Museo Nacional de Ciencias Naturales: Madrid, Spain, 2000; Volume 12.

76. The International Union for Conservation of Nature (IUCN) Red List of Threatened Species. Version 2020-1. Available online: https:/ / www.iucnredlist.org (accessed on 8 August 2021).

77. Dobson, A.J.; Barnett, A.G. An Introduction to Generalized Linear Models; CRC Press: Boca Raton, FL, USA, 2018.

78. Hilbe, J.M. Log negative binomial regression as a generalized linear model. Grad. Coll. Comm. Stat. 1993, $1024,1-16$.

79. Cameron, A.C.; Trivedi, P.K. Econometric models based on count data. Comparisons and applications on some estimators and tests. J. Appl. Econom. 1986, 1, 29-53. [CrossRef]

80. R Core Team. R: A language and Environment for Statistical Computing; R Foundation for Statistical Computing: Vienna, Austria, 2021. 
81. Pungetti, G. Conectividad Ambiental: Las áreas Protegidas en la Cuenca Mediterránea; Consejería de Medio ambiente, Junta de Andalucia: Sevilla, Spain, 2003.

82. Siemann, E.; Tilman, D.; Haarstad, J.; Ritchie, M. Experimental tests of the dependence of arthropod diversity on plant diversity. Am. Nat. 1998, 152, 738-750. [CrossRef]

83. Liu, Y.; Duan, M.; Zhang, X.; Zhang, X.; Yu, Z.; Axmacher, J.C.; Stewart, A.; Ewers, R. Effects of plant diversity, habitat and agricultural landscape structure on the functional diversity of carabid assemblages in the North China Plain. Insect Conserv. Diver. 2015, 8, 163-176. [CrossRef]

84. Danne, A.; Thomson, L.J.; Sharley, D.J.; Penfold, C.M.; Hoffmann, A.A. Effects on native grass cover crops on beneficial and pest invertebrates in Australian vineyards. Pest Manag. 2010, 39, 970-978. [CrossRef]

85. Eckert, M.; Mathulwe, L.L.; Gaigher, R.; Joubert-van der Merwe, L.; Pryke, J.S. Native cover crops enhance arthropod diversity in vineyards of the Cape Floristic Region. J. Ins. Conser. 2020, 24, 133-149. [CrossRef]

86. Sáenz-Romo, M.G.; Veas-Bernal, A.; Martínez-García, H.; Campos-Herrera, R.; Ibáñez-Pascual, S.; Martínez-Villar, E.; PérezMoreno, I.; Marco-Mancebón, V.S. Ground cover management in a Mediterranean vineyard: Impact on insect abundance and diversity. Agric. Ecosyst. Environ. 2019, 283, 106571. [CrossRef]

87. Sáenz-Romo, M.G.; Veas-Bernal, A.; Martínez-García, H.; Campos-Herrera, R.; Ibáñez-Pascual, S.; Martínez-Villar, E.; MarcoMancebón, V.S.; Pérez-Moreno, I. Effects of ground cover management on insect predators and pests in a Mediterranean vineyard. Insects 2019, 10, 421. [CrossRef]

88. Geldenhuys, M.; Gaigher, R.; Pryke, J.S.; Samways, M.J. Diverse herbaceous cover crops promote vineyard arthropod diversity across different management regimes. Agric. Ecosyst. Environ. 2021, 307, 107222. [CrossRef]

89. Sutter, L.; Jeanneret, P.; Bartual, A.M.; Bocci, G.; Albrecht, M. Enhancing plant diversity in agricultural landscapes promotes both rare bees and dominant crop-pollinating bees through complementary increase in key floral resources. J. Appl. Ecol. 2017, 54, 1856-1864. [CrossRef]

90. Hannon, L.E.; Sisk, T.D. Hedgerows in an agri-natural landscape: Potential habitat value for native bees. Biol. Conserv. 2009, 142, 2140-2154. [CrossRef]

91. Miranda-Barroso, L.; Aguado, O.; Falcó-Garí, J.V.; Lopez, D.; Schade, M.; Vasileiadis, V.; Peris-Felipo, F.J. Multifunctional areas as a tool to enhance biodiversity and promote conservation in alfalfa fields. J. Ins. Biodiver. Syst. 2021, 7, $251-261$.

92. Peris-Felipo, F.J.; Santa, F.; Aguado, O.; Falcó-Garí, J.V.; Iborra, A.; Schade, M.; Brittain, C.; Vasileiadis, V.; Miranda-Barroso, L. Enhancement of the diversity of pollinators and beneficial insects in intensively managed vineyards. Insects 2021, 12, 740. [CrossRef]

93. Carvalheiro, L.G.; Veldtman, R.; Shenkute, A.G.; Tesfay, G.B.; Pirk, C.W.W.; Donaldson, J.S.; Nicolson, S.W. Natural and within farmland biodiversity enhances crop productivity. Ecol. Lett. 2011, 14, 251-259. [CrossRef]

94. Paiola, A.; Assandri, G.; Brambilla, M.; Zottini, M.; Pedrini, P.; Nascimbene, J. Exploring the potential of vineyards for biodiversitymediated ecosystem services: A global-scale systematic review. Sci. Total Environ. 2020, 706, 135839. [CrossRef] 